\title{
Apparent selectivity of sheep in deferred marandu palisadegrass pastures with variable initial heights
}

\author{
[Seletividade aparente de ovinos em pastos de capim-marandu diferidos com \\ alturas iniciais variáveis] \\ M.E.R. Santos ${ }^{1}$, L.E.F. Afonso ${ }^{2}$, B.H.R. Carvalho ${ }^{3}$, A.C. Rêgo ${ }^{4}$, \\ G.J.S. Queiroz ${ }^{5}$, J.A.S. Medica ${ }^{3}$, L.S. Moraes ${ }^{1}$, L.L.S. Carmo ${ }^{1}$ \\ ${ }^{1}$ Faculdade de Medicina Veterinária - Universidade Federal de Uberlândia - Uberlândia, MG \\ ${ }^{2}$ Programa de pós-graduação - Universidade Federal Rural da Amazônia - Belém, PA \\ ${ }^{3}$ Programa de pós-graduação - Faculdade de Medicina Veterinária - Universidade Federal \\ de Uberlândia - Uberlândia, MG \\ ${ }_{4}^{4}$ Instituto da Saúde e Produção Animal - Universidade Federal Rural da Amazônia - Belém, PA \\ ${ }^{5}$ Aluno de graduação - Faculdade de Medicina Veterinária - Universidade Federal de Uberlândia - Uberlândia, MG
}

\begin{abstract}
The objective of this study was to evaluate the apparent selectivity of sheep in marandu palisadegrass (Urochloa brizantha cv. Marandu) pastures with four heights at the beginning of the deferment period $(15,25,35$ and $45 \mathrm{~cm})$. The deferment period was 92 days and started on 03/21/2014. Evaluations occurred in the beginning (first week), middle ( $45^{\text {th }}$ day) and end $\left(92^{\text {nd }}\right.$ day) of the grazing period, in winter (06/21/2014 to 09/21/2014). Deferred pastures with 15 and $25 \mathrm{~cm}$ presented lower forage mass (FM), but higher live leaf (LL) percentage in FM than deferred pastures with 35 and $45 \mathrm{~cm}$. The live stem percentage in the FM and the apparent selectivity index (ASI) of the LL were superior in the deferred pasture with $45 \mathrm{~cm}$. The dead stem (DS) percentage in the grazing simulation (GS) and the ASI of this morphological component were lower in the pasture with $15 \mathrm{~cm}$, compared to the deferred pasture with $45 \mathrm{~cm}$. The FM and the LL percentages in FM and in the GS sample decreased, while the DS percentages in FM and in GS sample increased with the grazing period. Marandu palisadegrass with $15 \mathrm{~cm}$ at beginning of the deferment period improves the morphology of the deferred pasture. Selective grazing is difficult during the grazing period.
\end{abstract}

Keywords: pasture deferment, forage mass, hand-plucked sample, Urochloa brizantha syn. Brachiaria brizantha

\section{RESUMO}

Objetivou-se avaliar a seletividade aparente de ovinos em pastos de capim-marandu (Urochloa brizantha cv. Marandu) com quatro alturas no início do diferimento $(15,25,35$ e $45 \mathrm{~cm})$. O período de diferimento foi de 92 dias e iniciou em 21/03/2014. As avaliações ocorreram no início (primeira semana), meio $\left(45^{\circ}\right.$ dia) e fim $\left(92^{\circ}\right.$ dia) do período de pastejo, no inverno (21/06/2014 a 21/09/2014). Os pastos diferidos com 15 e $25 \mathrm{~cm}$ apresentaram menor massa de forragem (MF), mas maior percentual de folha viva (FV) na MF do que os pastos diferidos com 35 e $45 \mathrm{~cm}$. O percentual de colmo vivo na MF e o indice de seletividade aparente (ISA) da FV foram superiores no pasto diferido com $45 \mathrm{~cm}$. O percentual de colmo morto (CM) na simulação de pastejo (SP) e o ISA desse componente morfológico foram menores no pasto diferido com $15 \mathrm{~cm}$, em comparação ao diferido com $45 \mathrm{~cm}$. A MF e os percentuais de FV na MF e na amostra de SP se reduziram, enquanto os percentuais de CM na MF e na amostra de SP aumentaram com o período de pastejo. O capim-marandu com $15 \mathrm{~cm}$ no início do período de diferimento melhora a morfologia do pasto diferido. O pastejo seletivo é dificultado no decorrer do período de pastejo.

Palavras-chave: diferimento da pastagem, massa de forragem, simulação manual de pastejo, Urochloa brizantha syn. Brachiaria brizantha 


\section{INTRODUCTION}

Selectivity is an inherent characteristic of grazing animals and, in monoculture pastures, can be characterized by the preferential consumption of some plant parts (live leaf), to the detriment of others (stem and dead material). The selectivity results in forage ingestion with better morphological composition (Santos et al., 2016) and nutritive value (Moraes et al., 2005), compared to the forage available in the pasture. In fact, selectivity may favor the performance of grazing animals.

When the deferment of pasture use occurs, it is possible to obtain high forage mass during winter, but with morphological composition generally unfavorable to animal consumption and performance, that is, with high stem and dead material percentages, but low live leaf percentage (Sousa et al., 2012; Vilela et al., 2012). In this condition, the animal selectivity can compensate the poor pasture quality and thus, avoid the reduction of animal performance.

However, if the morphology of deferred pasture is very unfavorable, the animal may find difficulty to select the live leaf and also to reject the live stem and dead material (Santos et al., 2016). This scenario can occur from the beginning and, especially, at the end of the use period of deferred pasture, in late winter (Silva et al., 2016). In this context, it is important to adopt management strategies that improve the morphology of deferred pasture and, consequently, facilitate the selectivity of grazing animals.

The reduction of sward height at the beginning of the deferment period, besides removing the old forage, may favor the appearance of new tillers, if this period is not long (Vilela et al., 2013). As a result, deferred pasture may present morphology that facilitates the selective grazing of the animals. In this sense, the evaluation of the apparent selectivity index of the morphological components of the pasture may be appropriate to test this hypothesis (Santos et al., 2016). The objective of this work was to understand how the variation of sward height at the beginning of the deferment period modifies the morphological characteristics of Brachiaria brizantha cv. Marandu syn. Urochloa brizantha cv. Marandu and, consequently, the apparent selectivity of the sheep during the winter.

\section{MATERIAL AND METHODS}

The work was approved by the Ethics Committee on the Use of Animals (CEUA/UFU), protocol number $031 / 13$. The study was carried out at the Federal University of Uberlândia, Uberlândia, MG, Brazil (18 $\left.30^{\circ} \mathrm{S}, 47^{\circ} 50^{\prime} \mathrm{W}\right)$, from January to September 2014. The experiment site has an altitude of $863 \mathrm{~m}$ and its climate is classified as Aw (Alvares et al., 2013). Climatic conditions during the experimental period were monitored (Table 1).

Table 1. Mean air temperatures, mean solar radiation, monthly rainfall and evapotranspiration during the experimental period

\begin{tabular}{lllllll}
\hline \multirow{2}{*}{ Period } & \multicolumn{2}{l}{ Mean air temperature $\left({ }^{\circ} \mathrm{C}\right)$} & $\begin{array}{l}\text { Solar } \\
\text { radiation } \\
(\mathrm{Mj} / \text { day })\end{array}$ & $\begin{array}{l}\text { Rainfall } \\
(\mathrm{mm})\end{array}$ & $\begin{array}{l}\text { Evapotranspiration } \\
(\mathrm{mm})\end{array}$ \\
\cline { 2 - 6 } & Average & Minimum & Maximum & & \\
\hline Jan-Mar/2014 & 23.60 & 18.60 & 29.80 & 579.97 & 79.13 & 95.83 \\
Apr-Jun/2014 & 21.46 & 12.03 & 30.03 & 475.11 & 44.19 & 77.50 \\
Jul-Sep/2014 & 21.32 & 10.88 & 31.93 & 490.25 & 25.19 & 85.49 \\
\hline
\end{tabular}

${ }^{1}$ period prior to deferment; ${ }^{2}$ deferment period; ${ }^{3}$ grazing period.

The experiment was carried out on pasture with Brachiaria brizantha cv. Marandu syn. Urochloa brizantha cv. Marandu (marandu palisadegrass), subdivided in 12 paddocks (experimental units) of $800 \mathrm{~m}^{2}$. The results of the soil chemical analysis obtained at the beginning of the experiment and in the $0-20 \mathrm{~cm}$ layer were: $\mathrm{pH}$
$\left(\mathrm{H}_{2} \mathrm{O}\right): 6.0 ; \quad \mathrm{P}: \quad 6.3 \mathrm{mg} / \mathrm{dm}^{3} \quad$ (Mehlich-1); $\mathrm{K}^{+}$: $153.0 \mathrm{mg} / \mathrm{dm}^{3} ; \quad \mathrm{Ca}^{2+}: \quad 5.0 \mathrm{cmol}_{\mathrm{c}} / \mathrm{dm}^{3} ; \quad \mathrm{Mg}^{2+}$ : $2.0 \mathrm{cmol}_{\mathrm{c}} / \mathrm{dm}^{3} ; \quad \mathrm{Al}^{3+}$ : $0.0 \mathrm{cmol}_{\mathrm{c}} / \mathrm{dm}^{3} \quad(\mathrm{KCl} 1$ mol/L); effective CTC: 7.39; CTC at $\mathrm{pH} \mathrm{7,0:}$ 10.69; and base saturation: $69.0 \%$. Based on these results and according to the recommendations of Cantarutti et al. (1999) for a 
medium level technological system, $50 \mathrm{~kg} / \mathrm{ha}$ of $\mathrm{N}$ and $\mathrm{P}_{2} \mathrm{O}_{5}$ were applied in January, in addition to $50 \mathrm{~kg} / \mathrm{ha}$ of $\mathrm{N}$ in March. Simple superphosphate and urea were used as fertilizer sources.

The experiment was conducted in a completely randomized design with three replicates. Four sward heights $(15,25,35$ and $45 \mathrm{~cm})$ were evaluated at the beginning of the deferment period. After the deferment period, all pastures were evaluated, with measures repeated in time, during the beginning ( $7^{\text {th }}$ day), middle $\left(45^{\text {th }}\right.$ day) and end $\left(92^{\text {th }}\right.$ day) of the grazing period. Before the deferment period, from January to March, all the paddocks were managed in continuous stocking with sheep and variable stocking rate to maintain the desired average sward heights, according to the treatments. The mean sward height was measured twice a week, with a graduated role and in 30 points per paddock. The average sward heights were controlled with the addition or removal of sheep from the paddocks. The 92 day deferment period started on $03 / 21 / 2014$. After the deferment period, all pastures were managed in continuous stocking and fixed stocking rate, using Santa Inês $\mathrm{x}$ Dorper crossbred sheep. The allocation of the animals to the paddocks was done at random to maintain the same initial stocking rate $(4.0$ animal unit - AU/ha). For this, 36 adult sheep with an average weight of $48 \mathrm{~kg}$ were used, and three animals were distributed per paddock. The animals received supplementation with concentrate, with average consumption of $180 \mathrm{~g}$ animal/day, throughout the grazing period in the winter $(06 / 21 / 2014$ to $09 / 19 / 2014)$.

On the $7^{\text {th }}$ day (beginning), on the $45^{\text {th }}$ day (middle) and on the $92^{\text {th }}$ day (end) of the grazing period all evaluations were performed. The mass and the morphological composition of the forage were obtained by harvesting close to the soil of the tillers contained within a square of $0.25 \mathrm{~m}^{2}$ at three points of sampling per paddock. At these points, the average plant height was similar to the average sward height. Each sample was weighed and subdivided into two subsamples. One was separated into live leaf, live stem, dead leaf and dead stem. When present, inflorescences were included in the live stem fraction. All morphological components were dried in a forced air circulation oven at $65^{\circ} \mathrm{C}$ for 72 hours and then weighed to calculate the percentages of the morphological components in the forage mass. The other sub-sample was weighed, dried under the same conditions as before and reweighed in order to estimate the sward forage mass.

The forage harvesting by manual grazing simulation was also performed by a single evaluator during the whole experimental period to avoid variations in each sample. Each of the three animals present in the paddocks was observed during the grazing activity, trying to identify the morphological component (live leaf, live stem, dead leaf and dead stem) consumed. Then, the evaluator collected a sample similar to the forage ingested by each animal. Thus, from each paddock, three samples were collected through the manual grazing simulation, one for each animal present in the paddock. Subsequently, these three samples were collected in order to compose a single composite sample representative of the paddock. This composite sample was separated into live leaf, live stem, dead leaf and dead stem, adopting the same criteria described previously. Each sub-sample of each morphological component was dried in a forced air circulation oven at $65^{\circ} \mathrm{C}$ for 72 hours and weighed to obtain the relative participation of each morphological component of the simulated grazing samples.

The apparent selectivity exerted by the animals in relation to the different morphological components of the pasture was evaluated based on the following equation used by Santos et al. (2016): ASI = GS/AF, where: ASI = apparent selectivity index; GS = morphological component in the grazing simulation sample (\%); $\mathrm{AF}=$ morphological component in the available forage sample (\%).

For analysis of the data, we performed the analysis of variance in a completely randomized design using the Proc Mixed of the SAS. The covariance matrices were chosen using the Akaike information criterion (Wolfinger, 1993). The effects of height and grazing period and their interaction were considered fixed. The days of the grazing period were considered measures repeated over time. The mean averages were compared by the Tukey test, adopting up to $5 \%$ as critical level of probability for the occurrence of type I error. 


\section{RESULTS AND DISCUSSION}

Among the thirteen variables studied, ten were influenced $(\mathrm{P}<0.05)$ by the sward height and by the grazing period in an isolated way, without interaction between these factors. Only three responses were influenced $(\mathrm{P}<0.05)$ by the interaction between sward height and grazing period (Table 2).

Table 2. Significance for the effects of sward height, grazing period and its interaction for the variable responses measured in the pastures of marandu palisadegrass

\begin{tabular}{cccc}
\hline \multirow{2}{*}{ Variable } & \multicolumn{3}{c}{ Factor } \\
\cline { 2 - 4 } & Sward height & Grazing period & Sward height x Grazing period \\
\hline FM & 0.0005 & $<0.0001$ & 0.3014 \\
LS in the FM & $<0.0001$ & 0.0080 & 0.5500 \\
DL in the FM & 0.2660 & 0.5901 & $<0.0001$ \\
DS in the FM & 0.0371 & 0.7600 & 0.0020 \\
LL in the GS & 0.0015 & $<0.0001$ & 0.3999 \\
LS in the GS & 0.0004 & $<0.0001$ & 0.7008 \\
DL in the GS & 0.6200 & $<0.0001$ & 0.1174 \\
DS in the GS & 0.0002 & 0.4250 & 0.0049 \\
ASI of LL & $<0.0001$ & 0.0096 & 0.2223 \\
ASI of LS & 0.0411 & 0.0070 & 0.0848 \\
ASI of DL & 0.0187 & 0.0004 & 0.8890 \\
ASI of DS & $<0.0001$ & 0.0220 & 0.4011 \\
\hline
\end{tabular}

FM: forage mass (kg/ha of DM); LL: live leaf (\%); LS: live stem (\%); DL: dead leaf (\%); DS: dead stem (\%); GS: grazing simulation sample; ASI: apparent selectivity index.

Deferred pastures with 15 and $25 \mathrm{~cm}$ presented lower $(\mathrm{P}<0.05)$ forage mass $(\mathrm{FM})$ compared to those deferred with 35 and $45 \mathrm{~cm}$. Considering that the FM of the deferred pasture is the sum of its FM at the beginning of the deferment period and the herbage accumulation during this period, and that there is a positive relation between the FM and the sward height (Nantes et al., 2013; Paula et al., 2012), the highest FM in the deferred pastures with 35 and $45 \mathrm{~cm}$, in relation to those with 15 and $25 \mathrm{~cm}$ (Table 3 ), is justified.

Table 3. Characteristics of marandu palisadegrass, of grazing simulation samples and apparent selectivity index (ASI) of sheep in deferred pastures with sward height variation

\begin{tabular}{|c|c|c|c|c|c|}
\hline \multirow{2}{*}{ Characteristic } & \multicolumn{4}{|c|}{ Sward height $(\mathrm{cm})$} & \multirow{2}{*}{ SEM } \\
\hline & 15 & 25 & 35 & 45 & \\
\hline Forage mass $(\mathrm{FM})$ & $4,043 \mathrm{~b}$ & $4,366 b$ & $5,289 \mathrm{a}$ & $5,626 a$ & 374.0 \\
\hline Live leaf in the FM (\%) & $13.8 \mathrm{a}$ & $9.6 \mathrm{~b}$ & $7.4 \mathrm{c}$ & $5.8 \mathrm{c}$ & 1.7 \\
\hline Dead stem in the FM $(\%)$ & $20.3 \mathrm{a}$ & $27.0 \mathrm{a}$ & $24.3 \mathrm{a}$ & $22.8 \mathrm{a}$ & 1.4 \\
\hline Live leaf in the GS (\%) & $46.1 \mathrm{a}$ & $42.8 \mathrm{a}$ & $41.9 \mathrm{a}$ & $28.6 b$ & 3.9 \\
\hline Live stem in the GS (\%) & $9.3 \mathrm{~b}$ & $10.7 \mathrm{~b}$ & $11.9 \mathrm{~b}$ & $14.7 \mathrm{a}$ & 1.1 \\
\hline Dead stem in the GS $(\%)$ & $12.7 \mathrm{~b}$ & $14.7 \mathrm{ab}$ & $15.0 \mathrm{ab}$ & $17.8 \mathrm{a}$ & 1.0 \\
\hline ASI of live leaf & $4.9 \mathrm{~b}$ & $5.1 \mathrm{~b}$ & $7.6 \mathrm{a}$ & $5.9 \mathrm{~b}$ & 0.6 \\
\hline ASI of live stem & $0.2 \mathrm{a}$ & $0.3 \mathrm{a}$ & $0.2 \mathrm{a}$ & $0.3 \mathrm{a}$ & 0.03 \\
\hline ASI of dead leaf & $1.3 \mathrm{~b}$ & $1.4 \mathrm{~b}$ & $1.6 \mathrm{~b}$ & $2.2 \mathrm{a}$ & 0.20 \\
\hline ASI of dead stem & $0.5 \mathrm{~b}$ & $0.5 \mathrm{~b}$ & $0.6 \mathrm{ab}$ & $0.8 \mathrm{a}$ & 0.07 \\
\hline
\end{tabular}

GS: grazing simulation sample; SEM: standard error of mean; For each characteristic, means followed by different letters differ by the Tukey test $(\mathrm{P}<0.05)$.

The highest deferred pastures probably had a population of older tillers at the beginning of the deferment period, since tall grasses have less tiller renewal than low grasses (Santana et al.,
2014). These older tillers, with lower $(\mathrm{P}<0.05)$ live leaf percentage (Santos et al., 2010a), developed during and after deferment, and resulted in lower $(\mathrm{P}<0.05)$ live leaf percentage 
during the winter in the deferred pastures with 35 and $45 \mathrm{~cm}$, when compared to those deferred with 15 and $25 \mathrm{~cm}$ (Table 3 ).

The highest $(\mathrm{P}<0.05)$ live stem percentage in higher deferred pastures (Table 4) can be justified by the higher height of these pastures during the grazing period. High grasses are also composed by tall plants and therefore are heavier. Thus, in these plants, the stem, a structural organ, is more developed in order to guarantee the support of the tillers. The increase of the stem percentage in the pasture can reduce the forage nutritive value (Nave et al., 2010), as well as make it difficult to graze the animals (Benvenutti et al., 2008).

Table 4. Characteristics of the marandu palisadegrass pastures and of grazing simulation samples in deferred pastures with variable sward heights

\begin{tabular}{|c|c|c|c|c|c|}
\hline \multirow{2}{*}{$\begin{array}{l}\text { Grazing } \\
\text { period }\end{array}$} & \multicolumn{4}{|c|}{ Sward height $(\mathrm{cm})$ at beginning of deferment period } & \multirow{2}{*}{ SEM } \\
\hline & 15 & 25 & 35 & 45 & \\
\hline & \multicolumn{4}{|c|}{ Live stem $(\%)$ in the forage mass } & \\
\hline Beginning & $38.1 \mathrm{bB}$ & $37.3 \mathrm{bA}$ & 41.2abB & $45.7 \mathrm{aB}$ & \multirow{3}{*}{1.7} \\
\hline Middle & $41.6 \mathrm{bA}$ & $38.1 \mathrm{bA}$ & $51.9 \mathrm{aA}$ & $51.3 \mathrm{aA}$ & \\
\hline \multirow{2}{*}{ End } & $42.2 \mathrm{bA}$ & $39.7 \mathrm{bA}$ & $50.2 \mathrm{aA}$ & $53.5 \mathrm{aA}$ & \\
\hline & \multicolumn{4}{|c|}{ Dead leaf $(\%)$ in the forage mass } & \multirow{4}{*}{1.4} \\
\hline Beginning & $24.8 \mathrm{aB}$ & $27.9 \mathrm{aA}$ & $23.7 \mathrm{aA}$ & $27.4 \mathrm{aA}$ & \\
\hline Middle & $29.1 \mathrm{aA}$ & $26.8 \mathrm{aA}$ & $20.6 \mathrm{bAB}$ & 23.6abB & \\
\hline \multirow[t]{2}{*}{ End } & $21.7 \mathrm{aB}$ & $20.5 \mathrm{aB}$ & $17.4 \mathrm{bB}$ & $12.9 \mathrm{bC}$ & \\
\hline & \multicolumn{4}{|c|}{ Dead leaf $(\%)$ in the grazing simulation sample } & \\
\hline Beginning & $17.4 \mathrm{bC}$ & $15.0 \mathrm{bC}$ & $15.7 \mathrm{bC}$ & $33.5 \mathrm{aB}$ & \multirow{3}{*}{4.2} \\
\hline Middle & $28.6 \mathrm{aB}$ & $26.8 \mathrm{aB}$ & $30.3 \mathrm{aB}$ & $27.4 \mathrm{aC}$ & \\
\hline End & $49.5 \mathrm{aA}$ & $53.5 \mathrm{aA}$ & $47.5 \mathrm{aA}$ & $55.8 \mathrm{aA}$ & \\
\hline
\end{tabular}

SEM: standard error of mean; For each characteristic, averages followed by the same letter, lowercase in the row and upper case in the column, do not differ by the Tukey test $(\mathrm{P}>0.05)$.

The dead stem percentage in FM and the apparent selectivity index (ASI) of live stem did not vary $(\mathrm{P}>0.05)$ among deferred swards (Table $3)$. However, in general, the lower live leaf percentage in the higher deferred swards, compared to the lower deferral swards, influenced the animals' selective grazing, which also resulted in a similar response pattern in this morphological component in the grazing simulation sample (Table 3).

The best structure of 15 and $25 \mathrm{~cm}$ deferred pastures, when compared to deferred pastures at 35 and $45 \mathrm{~cm}$ (Table 3), facilitated the consumption of live leaf by grazing animals in the lower deferred pastures. The ease of consumption of the live leaf can be demonstrated by the reduction of the ASI of this morphological component (Santos et al., 2016). When this happens, it can be inferred that the animal was in front of a pasture with high live leaf percentage, which makes it unnecessary that it exerts high selectivity for this morphological component. Really, the ASI of the live leaf was lower $(\mathrm{P}<0.05)$ in the deferred pasture with $15 \mathrm{~cm}$ than in the one with $35 \mathrm{~cm}$ (Table 3 ).
The dead stem percentage in the GS and the ASI of this morphological component were lower $(\mathrm{P}<0.05)$ in the deferred pasture with $15 \mathrm{~cm}$ compared to the deferred pasture with $45 \mathrm{~cm}$ (Table 3). These results demonstrate that sheep were more likely to reject the dead stem in the lower pasture, which also indicates that the deferred pasture at $15 \mathrm{~cm}$ had a structure which facilitated the animals' selective grazing.

In the middle and especially at the end of the grazing period, the lowest deferred pastures presented $(\mathrm{P}<0.05)$, in general, a higher dead leaf percentage than the highest pastures (Table 5). Probably a large part of the live leaf of the lowest pasture died in the middle and end of the grazing period, which increased the dead leaf percentage. On the other hand, it is possible that the lowest amount of live leaf of the highest deferred pasture (Table 3) has limited the selective grazing of the sheep by this morphological component (Santos et al., 2016). With this, the animals started to consume more dead leaf, which reduced their percentage in the pasture during the middle and end of the grazing period (Table 4). In fact, during the grazing period of 
the deferred pasture with $45 \mathrm{~cm}$, the dead leaf percentage reduced, indicating that the sheep consumed it in this condition of shortage of live leaf (Table 5). This argument is reinforced by the greater $(\mathrm{P}<0.05)$ ASI of the dead leaf by the sheep in the $45 \mathrm{~cm}$ deferred pasture and during the end of the grazing period (Table 3 ).

Table 5. Characteristics of marandu palisadegrass, grazing simulation samples and apparent selectivity index (ASI) of sheep during grazing period of deferred pastures

\begin{tabular}{lllll}
\hline \multirow{2}{*}{ Characteristic } & Grazing period & & \multirow{2}{*}{ SEM } \\
\cline { 2 - 4 } & Beginning & Middle & End & 864.0 \\
\hline Forage mass (FM) & $6,064 \mathrm{a}$ & $5,263 \mathrm{~b}$ & $3,166 \mathrm{c}$ & 5.0 \\
Live leaf in the FM (\%) & $18.8 \mathrm{a}$ & $6.0 \mathrm{~b}$ & $2.5 \mathrm{c}$ & 5.2 \\
Dead stem in the FM (\%) & $14.8 \mathrm{c}$ & $23.2 \mathrm{~b}$ & $32.9 \mathrm{a}$ & 14.1 \\
Live leaf in the GS (\%) & $66.8 \mathrm{a}$ & $33.7 \mathrm{~b}$ & $19.1 \mathrm{c}$ & 3.2 \\
Live stem in the GS (\%) & $9.5 \mathrm{~b}$ & $17.9 \mathrm{a}$ & $7.5 \mathrm{~b}$ & 5.9 \\
Dead stem in the GS (\%) & $3.3 \mathrm{~b}$ & $20.1 \mathrm{a}$ & $21.8 \mathrm{a}$ & 1.1 \\
ASI of live leaf & $3.8 \mathrm{~b}$ & $6.3 \mathrm{a}$ & $7.5 \mathrm{a}$ & 0.07 \\
ASI of live stem & $0.2 \mathrm{a}$ & $0.4 \mathrm{a}$ & $0.2 \mathrm{a}$ & 0.7 \\
ASI of dead leaf & $0.8 \mathrm{c}$ & $1.2 \mathrm{~b}$ & $3.0 \mathrm{a}$ & 0.21 \\
ASI of dead stem & $0.2 \mathrm{~b}$ & $0.9 \mathrm{a}$ & $0.7 \mathrm{a}$ & \\
\hline
\end{tabular}

GS: grazing simulation sample; SEM: standard error of mean; For each characteristic, means followed by different letters differ by the Tukey test $(\mathrm{P}<0.05)$

Higher grasses generally intercept more light (Pedreira and Pedreira, 2007; Silveira et al., 2013), which increases the shading within the forage canopy. In this sense, the self-shading may have been higher in the higher pastures than in the lower deferred pastures. In the condition of more intense shading inside the canopy, there is usually greater leaf senescence. However, in this study, dead leaf percentage did not change $(\mathrm{P}>0.05)$ among deferred pastures in the beginning of the grazing period (Table 5). It is possible that part of the dead leaves of the higher deferred pastures had detached from the tillers, becoming litter, which prevented differences in the dead leaf percentage between the pastures.

Greater competition for light inside the tallest pasture also accentuates the stem elongation (Pedreira and Pedreira, 2007). Therefore, during the beginning of the grazing period, the highest $(\mathrm{P}<0.05)$ percentage live stem in the FM occurred in the pasture deferred with $45 \mathrm{~cm}$ than in those deferred with 15 and $25 \mathrm{~cm}$. In the middle and end of the grazing period, the live stem percentage in FM were higher $(\mathrm{P}<0.05)$ in the deferred pastures with 35 and $45 \mathrm{~cm}$, compared to those with 15 and $25 \mathrm{~cm}$ (Table 5).

Forage mass (FM) and live leaf percentage in the FM and in the GS reduced $(\mathrm{P}<0.05)$ with the grazing period, while the dead stem percentage in the FM and in the GS sample, as well such as
ASI of live leaf, of dead leaf and of dead stem increased $(\mathrm{P}<0.05)$. The live stem percentage in the GS was $(\mathrm{P}<0.05)$ higher in the middle compared to the beginning and end of the grazing period. The ASI of the live stem did not vary $(\mathrm{P}>0.05)$ throughout the grazing period (Table 4).

During the grazing period, from June to September, the minimum temperature was below $15^{\circ} \mathrm{C}$ (Table 1), which impairs the growth of tropical grasses. In addition, during this period rainfall was low and evapotranspiration was high (Table 1). Thus, after grazing by sheep, regrowth was impaired. With this, the FM of the pastures reduced during the grazing period (Table 4). As the grazing animals prefer the live leaf and reject the dead stem (Santos et al., 2016), the live leaf percentage decreased while that dead stem increased during the grazing period (Table 4). These results indicate that, during the grazing period, the structural characteristics of the deferred pasture worsen, as reported by Silva et al. (2016).

Except for the deferred pasture with $25 \mathrm{~cm}$, the others showed $(\mathrm{P}<0.05)$ a lower live stem percentage in FM at the beginning, compared to the middle and end of the grazing period (Table 5). It is possible that the greater forage shortage at the end of the grazing period has caused a faster disappearance of the live leaf and, 
as already discussed, a higher consumption of dead leaf. With the reduction of these two morphological components of the deferred pastures, the percentage of live stem increased proportionally in the forage mass (Table 5).

The high live stem percentage in the grazing simulation sample (GS) during the middle of the grazing period (Table 4) may have been caused by the consumption of inflorescence by sheep, because in this work the inflorescences were included in the stem alive. With the passage of the grazing period, the pasture structure worsened, and the available forage mass decreased (Table 4), which caused difficulty of the sheep in selecting the live leaf. Thus, the animal had to modify the morphological composition of the ingested diet in relation to the pasture offered, which made the apparent selectivity index of the live leaf increase after the beginning of the grazing period (Table 4).

The apparent selectivity index (ASI) of the dead leaf and the dead stem increased from the beginning to the end of the grazing period (Table 3 ), because in a situation limiting the live leaf availability, the sheep begin to consume the dead leaf (Table 5). It presents better nutritional value than the live stem and the dead stem (Santos et al., 2010b). In addition, in an attempt to apprehend the few live leaves that are entangled in the large amount of dead forage in the deferred pasture, the sheep end up eating more dead leaves and stems. This process may have occurred more markedly at the end of the grazing period of the higher deferred pastures, which would justify the higher ASI values of the dead leaf and stem (Table 3).

It was observed that only at the beginning of the grazing period the sheep were able to reject $($ ASI $<1.0)$ the dead leaf (Table 4). This indicates that the pasture structure was more unfavorable to the animal selectivity during the middle and the end of the grazing period, which was a consequence of the worse morphological composition of these pastures during the grazing period.

The results presented in this work demonstrate that the maintenance of the lowest marandu palisadegrass pasture $(15 \mathrm{~cm})$ at the beginning of the deferment period has the potential to increase the animal performance in deferred pastures.
However, during the grazing period in winter, pasture morphology becomes unfavorable to live leaf selection, which may limit the animal performance. To avoid this, management strategies could be adopted, such as the supply of supplementary concentrate to the animals, especially at the end of the grazing period. In addition, the stepwise deferment, which consists of subdividing the pasture into paddocks and deffer then in at different times, would also reduce the average grazing time of the deferred paddocks during the winter.

\section{CONCLUSIONS}

The maintenance of the marandu palisadegrass with $15 \mathrm{~cm}$ at the beginning of the deferment period improves the morphological composition of the deferred pasture and facilitates the selective grazing of the sheep during the winter. With the reduction of the forage mass and the degradation of the pasture structure during the grazing period in the winter, the animals have an apparent difficulty to select the live leaf, as well as to reject the dead forage present in the deferred pasture.

\section{ACKNOWLEDGEMENTS}

To the Conselho Nacional de Desenvolvimento Científico e Tecnológico (CNPq), the Fundação de Amparo à Pesquisa do Estado de Minas Gerais (FAPEMIG), and the Fundação de Apoio Universitário for the financial support.

\section{REFERENCES}

ALVARES, C.A.; STAPE, J.L.; SENTELHAS, P.C. et al. Köppen's climate classification map for Brazil. Meteorol. Zeitsch., v.22, p.711-728, 2013.

BENVENUTTI, M.A.; GORDON, I.J.; POPPI, D.P. The effects of stem density of tropical swards and age of grazing cattle on their foraging behaviour. Grass Forage Sci., v.63, p.1-8, 2008.

CANTARUTTI, R.B.; ALVAREZ V.V.H.; RIBEIRO, A.C. Pastagens. In: RIBEIRO, A.C.; GUIMARÃES, P.T.G.; ALVAREZ, V.V.H. (Eds.). Recomendações para uso de corretivos $e$ fertilizantes em Minas Gerais - $5^{\text {a }}$ aproximação. Viçosa, MG: UFV, 1999. p.332-341. 
MORAES, E.H.B.K.; PAULINO, M.P.; ZERVOUDAKIS, J.T. et al. Avaliação qualitativa da pastagem diferida de Brachiaria decumbens Stapf. sob pastejo, no período da seca, por intermédio de três métodos de amostragem. Rev. Bras. Zootec., v.34, p.30-35, 2005.

NANTES, N.N.; EUCLIDES, V.P.B.; MONTAGNER, D.B. et al. Desempenho animal e características de pastos de capim-piatã submetidos a diferentes intensidades de pastejo. Pesqui. Agropecu. Bras., v.48, p.114-121, 2013.

NAVE, R.L.G.; PEDREIRA, C.G.S.; PEDREIRA, B.C. Nutritive value and physical characteristics of Xaraes palisadegrass as affected by grazing strategy. J. Anim. Sci., v.40, p.285-293, 2010.

PAULA, C.C.L.; EUCLIDES, V.P.B.; MONTAGNER, D.B. et al. Estrutura do dossel, consumo e desempenho animal em pastos de capim-marandu sob lotação contínua. Arq. Bras. Med. Vet. Zootec., v.64, p.169-176, 2012.

PEDREIRA， B.C.; PEDREIRA， C.G.S. Fotossíntese foliar do capim-xaraés [Brachiaria brizantha (A. Rich.) Stapf. cv. Xaraés] e modelagem da assimilação potencial de dosséis sob estratégias de pastejo rotativo. Rev. Bras. Zootec., v.36, p.773-779, 2007.

SANTANA, S.S.; FONSECA, D.M.; SANTOS, M.E.R. et al. Initial height of pasture deferred and utilized in winter and tillering dynamics of signal grass during the following spring. Acta Sci. Anim. Sci., v.36, p.17-23, 2014.

SANTOS, M.E.R.; FONSECA, D.M.; BALBINO, E.M. et al. Correlações entre características estruturais e valor nutritivo de perfilhos em pastos de capim-braquiária diferidos e adubados com nitrogênio. Rev. Bras. Saúde Prod. Anim., v.11, p.595-605, 2010a.
SANTOS, M.E.R.; FONSECA, D.M.; BALBINO, E.M. et al. Valor nutritivo de perfilhos e componentes morfológicos em pastos de capim-braquiária diferidos e adubados com nitrogênio. Rev. Bras. Zootec., v.39, p.19191927, 2010b.

SANTOS, M.E.R.; FONSECA, D.M.; SOUSA, D.O.C. Seletividade aparente de bovinos em pastos de capim-braquiária sob períodos de diferimento. Arq. Bras. Med. Vet. Zootec., v.68, p.1655-1663, 2016.

SILVA, C.S.; MONTAGNER, D.P.; EUCLIDES, V.P.B. et al. Steer performance on deferred pastures of Brachiaria brizantha and Brachiaria decumbens. Ciênc. Rural, v.46, p.1998-2004, 2016.

SILVEIRA, M.C.T.; SILVA, S.C.; SOUZA JÚNIOR, S.J. et al. Herbage accumulation and grazing losses on Mulato grass subjected to strategies of rotational stocking management. Sci. Agríc., v.70, p.242-249, 2013.

SOUSA B.M.L.; VILELA, H.H.; SANTOS, M.E.R. et al. Characterization of tillers in deferred Piatã palisade grass with different initial heights and nitrogen levels. Rev. Bras. Zootec., v.41, p.1618-1624, 2012.

VILELA H.H.; SOUSA B.M.L.; SANTOS, M.E.R. et al. Characterization of tillers of piatã palisade grass deferred in the fall with varying heights and deferment periods. Acta Sci. Anim. Sci., v.35, p.21-27, 2013.

VILELA H.H.; SOUSA B.M.L.; SANTOS, M.E.R. et al. Forage mass and structure of piatã grass deferred at different heights and variable periods. Rev. Bras. Zootec., v.41, p.1625-1631, 2012.

WOLFINGER, R. Covariance structure selection in general mixed models. Commun. Stat. Simul. Comp., v.22, p.1079-1106, 1993. 